\title{
Dynamic Changes in Soil Physico-Chemical Properties with the Application of Inorganic Fertilizers
}

\author{
K. Theresa ${ }^{1 *}$, R. Shanmugasundaram ${ }^{1}$ and J.S. Kennedy ${ }^{2}$ \\ ${ }^{1}$ Department of Soil Science and Agricultural Chemistry, ${ }^{2}$ Department of Agricultural \\ Entomology, Tamil Nadu Agricultural University, Coimbatore- 03, India \\ *Corresponding author
}

A B S T R A C T

\begin{tabular}{|l|}
\hline K e y w o r d s \\
Soil pH, Electrical \\
Conductivity (EC), \\
Fertilizers
\end{tabular}

\section{Introduction}

Indispensible element of agriculture is soil and its inherent component evidently affects its agricultural value (Kieth et al., 2012). Agronomic technologies, which include fertilization practices, have a considerable, although not continually optimistic effect on soil residences (Naima et al., 2015). Over the past years the excessive, frequently
Imbalanced application of inorganic fertilizer generates undesirable over soil physicochemical properties to a great extent. Short term aerobic incubation experiment was implemented with soil samples (Typic Haplustert) collected from top soil horizon $(0-15 \mathrm{~cm})$ of cabbage field in Viraliyur, Coimbatore district of Tamil Nadu. Intention of study is towards examining the pattern of changes in $\mathrm{pH}$ and electrical conductivity (EC) in soil added with varied levels of fertilizers (NPK) under field capacity condition. Fertilizer was applied in accordance with the treatments viz., control (no fertilizer), $100 \%$ of RDF (100:125:25), $125 \%$ of N + Recommended PK, $150 \%$ of N + Recommended PK, $125 \%$ of P + Recommended NK, $150 \%$ of P + Recommended NK, $125 \%$ of K + Recommended NP, $150 \%$ of K + Recommended NP. Fertilizers source used were urea, diammonium phosphate (DAP) and muriate of potash (MOP). Experimental soil was characterized for its physicochemical. The $\mathrm{pH}$ was neutral in reaction and EC level was in safer limit. Incubation period was extended for two months. Destructive sample from each set of container was taken at weekly intervals for analysis of $\mathrm{pH}$ and $\mathrm{EC}$. From the experimental results, no significant changes in the $\mathrm{pH}$ and EC were recorded during the first three weeks of incubation. The acidification was most pronounced in soil receiving urea at 125 and 150 per cent recommended level. The slight change in $\mathrm{pH}$ and electrical conductivity was noticed after third week of incubation. A prominent change in soil reaction was induced by the urea applied at the rate of $150 \%+\operatorname{Rec}$ PK in comparison with other treatments. Salinity levels was greatly influenced in the DAP treated soils. 
production potential is greatly influenced by soil physical and chemical properties ( $\mathrm{Su}$ et al., 2002). Agronomic practice including chemical fertilization had a great influence over soil physico-chemical properties.

Average nutrient input-output balances significantly reduced from the 1990s; most soils in Tamil Nadu are sufficiently or even highly supplied with plant-available nutrients. This "legacy excess fertilizers" poses high and long-term risks to soil and water bodies (Sharpley et al., 2013). However, continued long term application of fertilizers can lead to accumulation in surface horizons greater than that required for optimum plant growth, thus increasing the potential for nutrient loss to surface waters and eutrophication (McDowell et al., 2001).

Application of such mineral fertilizers in the soil has several effects on the properties of soil, for example changes in soil salinity and soil reaction. It reflects the overall chemical status of the soil and influences a whole range of chemical and biological processes occurring in the soil. Because of its implications in most chemical reactions in the soil, knowing the actual value of soil $\mathrm{pH}$ and monitoring its changes is critical for understanding the physicochemical functioning of the soil (Jaillard et al., 2003).

With current levels of inorganic fertilizer used, the potential for fertilizers to have negative impacts on productivity and environmental quality is great, leading to productivity declines and environmental problems (Ogbodo, 2013).

Keeping the above points in view an incubation experiment with varied NPK levels was conducted to investigate the changes on soil reaction and electrical conductivity.

\section{Materials and Methods}

Laboratory incubation study was conducted in silty loam soil to assess the changes in soil reaction and EC as influenced by NPK fertilizers applied at varied levels. The experiment was carried out with completely randomized design replicated three times. The experimental set up was maintained for eight weeks. The fertilizer treatments comprised of: $\mathrm{T}_{1}-$ Control; $\mathrm{T}_{2}-100 \% \mathrm{RDF} ; \mathrm{T}_{3}-125 \% \mathrm{~N}$ $+\operatorname{Rec} \mathrm{PK} ; \mathrm{T}_{4}-150 \% \mathrm{~N}+\operatorname{Rec} \mathrm{PK} ; \mathrm{T}_{5}-125 \% \mathrm{P}$ + Rec NK; $\mathrm{T}_{6}-150 \% \mathrm{P}+\operatorname{Rec} \mathrm{NK} ; \mathrm{T}_{7}-125 \%$ $\mathrm{K}+\operatorname{Rec} \mathrm{NP} ; \mathrm{T}_{8^{-}} 150 \% \mathrm{~K}+\operatorname{Rec} \mathrm{NP}$. Recommended fertilizer rates for cabbage were $100: 125: 125 \mathrm{~kg}$ of NPK ha ${ }^{-1}$. Straight fertilizers viz., Urea, DAP and muriate of potash were applied for $\mathrm{N}, \mathrm{P}$ and $\mathrm{K}$ respectively. The study focused on the consequence of changes in soil reaction and EC by NPK fertilizers at varied levels in soil moistened at field capacity level.

\section{Preparation of Soil Medium}

The soil was collected from the upper layer of surface horizon at a depth of $0-15 \mathrm{~cm}$ at five sampling points randomly selected from cabbage grown farmer's field in Viraliyur, Coimbatore District. The sample was air dried, processed though $2 \mathrm{~mm}$ sieve and homogenized.

Polythene containers each carrying $100 \mathrm{~g}$ of processed soil with a capacity of $100 \mathrm{ml}$ were arranged in completely randomized design with three replicates. Required quantity of water was added to maintain the soil moisture at field capacity throughout the period of incubation (2 months) and the cups were kept open at room temperature. Soil moisture was monitored at 3 days intervals based on the weight of the cups and maintained at field capacity by the addition of distilled water. 
Analysis of soil for releasing pattern of nutrients

Destructive sample from each set of container was utilized for analysis at weekly intervals. Samples were estimated for physico-chemical properties. $\mathrm{pH}$ was measured in a 2:1 water/soil ratio with a shaking time of about 30 minutes (ELICO - LI615 pH meter). Salinity was determined by measuring the electrical conductivity of the saturated soil extract given by Jackson (1967) EC (ELICO CM 180 Conductivity meter).

\section{Results and Discussion}

Initial characteristics of soil used in the study

The composite soil collected from field was neutral in reaction and non-saline. The textural analysis revealed that it is silty clay loam in nature. The physical properties viz., bulk density, particle density, porosity and water holding capacity were $1.35\left(\mathrm{Mg} \mathrm{m}^{-3}\right), 2.64$ $\left(\mathrm{Mg} \mathrm{m}^{-3}\right), 47.3$ per cent and 40.1 per cent respectively. Organic carbon status was medium and the exchange reactions of soil in respect of cations were $13.4 \mathrm{cmol}\left(\mathrm{p}^{+}\right) \mathrm{kg}^{-1}$. Available nutrient status of soil with respect to $\mathrm{N}, \mathrm{P}$ and $\mathrm{K}$ showed high $\mathrm{K}\left(230 \mathrm{~kg} \mathrm{ha}^{-1}\right)$, medium $\mathrm{P} \quad\left(18 \mathrm{~kg} \mathrm{ha}^{-1}\right)$ and low $\mathrm{N}$ $\left(195 \mathrm{~kg} \mathrm{ha}^{-1}\right)$.

\section{Soil reaction affected by fertilizers}

\section{$\mathbf{N}$ fertilizer on soil pH}

Fate of chemical fertilizer use and its consequence on soil $\mathrm{pH}$ in acid, neutral and alkaline soil depends primarily its nature viz., acidic, alkaline, neutral and types (straight, complex or compound) and obviously its components.
The results revealed that, there was a temporary changing effect in $\mathrm{pH}$ was noticed in urea treated soil. Initially the soil $\mathrm{pH}$ was neutral (7.6) in reaction. In $100 \%$ NPK treated soil; the $\mathrm{pH}$ was increased from 7.6 to 8.2 and the escalating trend was seen up to 28 DAI with the highest $\mathrm{pH}$ of 8.2 recording during third week of study (Fig. 1). When the soil is high in carbonate content, the $\mathrm{pH}$ may not drop even though soil is added with acidic fertilizers (Glendining et al., 2017). In this case, the experimental soil with high carbonates content might be a factor for such increasing trend in $\mathrm{pH}$. With increasing period, inclination pattern declined and reached its stability toward its initial soil reaction at the end. The degree of change in soil $\mathrm{pH}$ on urea application depends on the buffering capacity of the soil.

Among the treatments, $\mathrm{N}$ applied @ 125\% and $150 \%$ excess than the recommended dose influenced the soil $\mathrm{pH}$ much more than other treatments. In $125 \% \mathrm{~N}+\mathrm{Rec}$. PK, the $\mathrm{pH}$ gets reduced within 7 DAI from 7.6 to 7.3 and further it was raised and reached a maximum of 7.9 at 42 DAI. After this period, the $\mathrm{pH}$ started declining and attained near initial range of 7.7 (Fig. 2a). The soil treated with 150\% N $+\mathrm{Rec}$ PK has also reduced soil $\mathrm{pH}$ as in $125 \% \mathrm{~N}$ applied soil. But in this case the reduction in $\mathrm{pH}$ was observed up to two weeks i.e., 14 DAI. The highest decline of 7.2 was also recorded in $150 \% \mathrm{~N}$ treated soil in accordance with the other fertilizer treatments (Fig. 2b). This is in line with the findings of Wells et al., (2014) who observed that, higher the dosage of urea resulted in maximum reduction of soil $\mathrm{pH}$. Thereafter the $\mathrm{pH}$ got raised and attained its stability at the end of the incubation. Hydrolysis of urea resulted in bicarbonate and ammonium- $\mathrm{N}$ formation and the bicarbonate ions then reacted with $\mathrm{H}^{+}$ions in the soil solution, which temporarily 
might have reduced acidity, but acidity is again produced when ammonium-N undergoes nitrification (Wardle, 1992). After decline, gradual increase in the $\mathrm{pH}$ was recorded and the same trend was seen up to 42 DAI in $150 \% \mathrm{~N}$ treated soil (Fig. 2b). Stability in the soil $\mathrm{pH}$ was observed at the end of the incubation. In case of $\mathrm{NH}_{3}{ }^{+}$liberation the soil $\mathrm{pH}$ will get increased but when it get lost or transformed to nitrate, the soil $\mathrm{pH}$ decreased. Urea is typically a fertilizer with acidifying nature in soil and nitrogenous fertilizers could decrease the soil $\mathrm{pH}$. This acidifying effect of nitrogenous fertilizers is in agreement with the findings of Hati et al., (2008) and Darusman et al., (1991), who also reported a decline in soil $\mathrm{pH}$ with application of nitrogenous fertilizers. This is mainly due to the fact that most fertilizers supply $\mathrm{N}$ as $\mathrm{NH}_{4}{ }^{+}$first, which upon oxidation releases $\mathrm{H}^{+}$ ions (Magdof et al., 1997).

Free hydrogen $\left(\mathrm{H}^{+}\right)$ions increase the acidity. Higher the percentage of ammonium in the fertilizer results in greater acidification potential. Ammonium-based fertilizers will acidify soil as they generate two $\mathrm{H}+$ ions for each ammonium molecule nitrified to nitrate (Lu et al., 2012). Moreover urea on hydrolysis leads to concomitant rise in soil $\mathrm{pH}$ due to the formation of easily decomposable ammonium carbonate that readily liberates ammonia (Erikson et al., 1985). Hence the significant effect of varied urea levels on soil reaction was observed when increasing the levels of $\mathrm{N}$ during period of incubation.

\section{P fertilizer on soil reaction}

There is a correlation between salt concentration and soil $\mathrm{pH}$ with a $\mathrm{pH}$ decrease accompanying salt leaching from the soil profile. In case of $\mathrm{P}$ fertilizer except DAP most of the $P$ fertilizers are acidic in nature and $\mathrm{P}$ can get adsorbed in both acidic/slightly alkaline conditions (Richards, 1969; Singh et $a l$. , 2007). The DAP, a salt of weak base which upon hydrolysis reaction of phosphate anion produces $\mathrm{OH}$ ions. Therefore the initial $\mathrm{pH}$ of soil due to application of this sort of fertilizer is slightly basic.

The DAP used in the study which is alkaline in nature and applied at a rate of $100 \%, 125 \%$ $\mathrm{P}+$ Rec NK and $150 \% \mathrm{P}+$ Rec NK. Application of DAP did not have much influence in altering soil $\mathrm{pH}$ in spite of its less acidifying potential. The soil applied with $125 \% \mathrm{P}$ reduces $\mathrm{pH}$ to small units from 7.6 to 7.55. From second week onwards irregular pattern of changes in soil $\mathrm{pH}$ was observed till end of the incubation period (Fig. 3a).

The form of $\mathrm{P}$ in diammonium phosphate (DAP) is $\mathrm{HPO}_{4}{ }^{2-}$ which can make acidic soils $(\mathrm{pH}<7.2)$ more alkaline but has no effect on soil with a $\mathrm{pH}>7.2$. Though the initial $\mathrm{pH}$ (neutral) on application of phosphate fertilizers may differ but after a few days or few weeks the differences may disappear.

Therefore, phosphate fertilizers may not alter soil pH conspicuously (Adhikari et al., 2014). The ammonium present in DAP is gradually converted to nitrate by soil bacteria, resulting in a subsequent drop in $\mathrm{pH}$. Among all the treatments except $100 \%$ NPK treated soil, $150 \% \mathrm{P}+\mathrm{Rec} \mathrm{NK}$ increased the $\mathrm{pH}$ from 7.6 to 7.7 and sudden turn down was noticed and the $\mathrm{pH}$ got reduced to the lowest level of 7.43 at 35 DAI (Fig. 3b).

This may be due to that at higher level (150\%) of $\mathrm{P}$ application higher ammonium would have been converted to nitrate along with $\mathrm{H}^{+}$ ions (Naima et al., 2015). At the end of the period the $\mathrm{pH}$ attained stable condition and it got reduced from its initial value. 
Fig.1 Pattern of change in the soil reaction by $100 \%$ NPK fertilizer during period of incubation

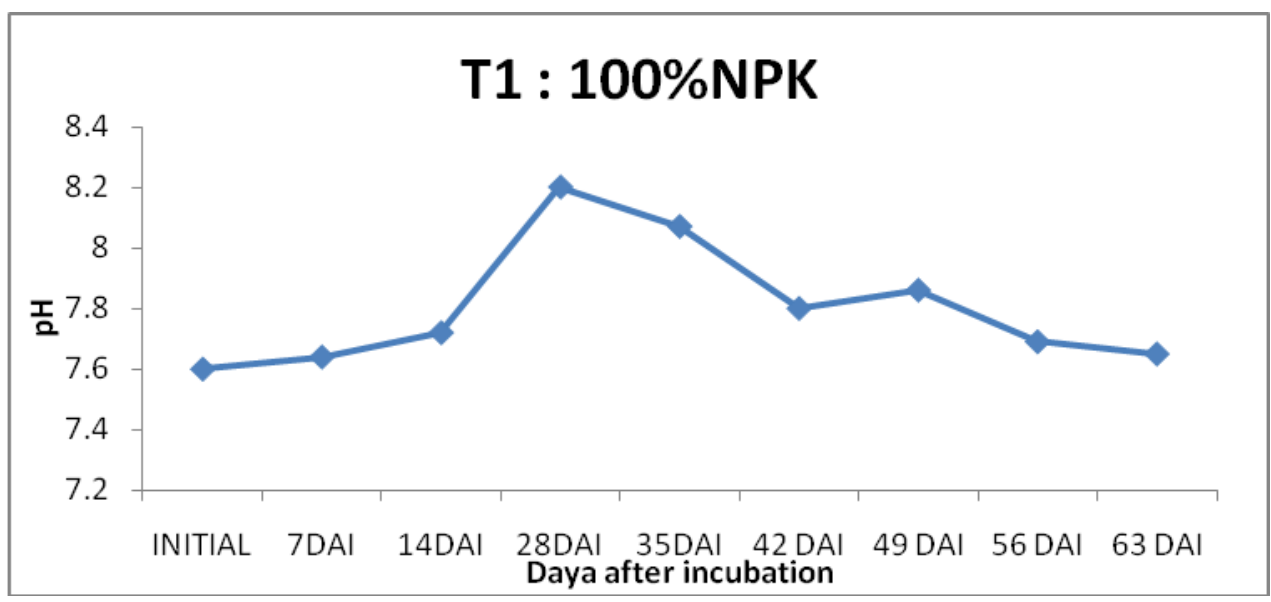

Fig.2a Pattern of change in soil reaction changing pattern by $125 \% \mathrm{~N}+$ Rec. PK fertilizer during period of incubation

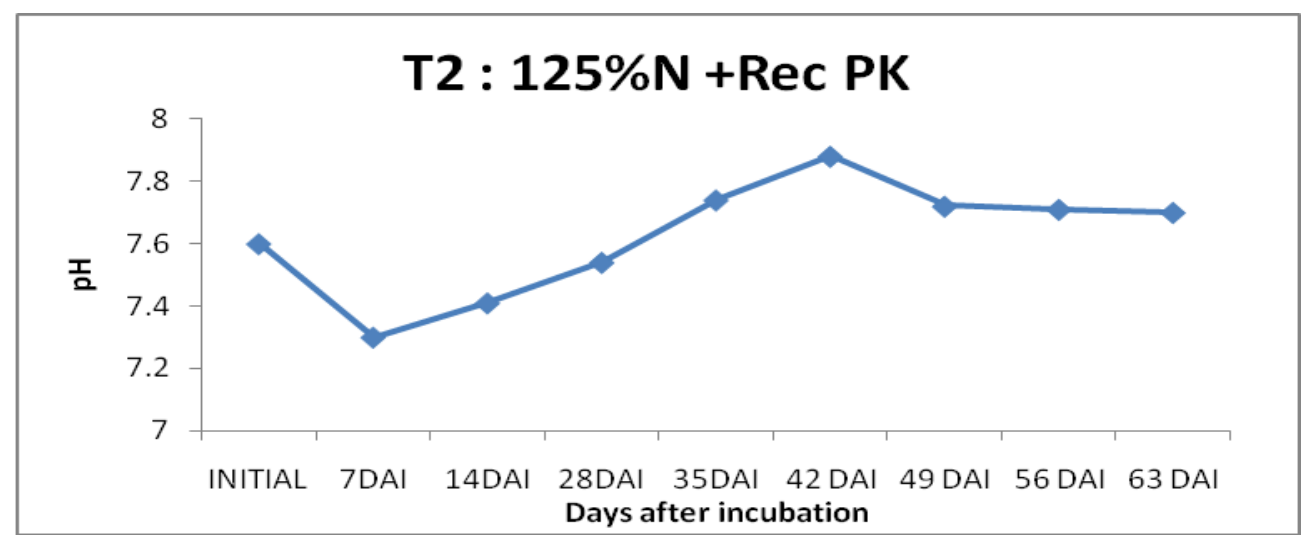

Fig.2b Pattern of change in soil reaction changing pattern by $150 \% \mathrm{~N}+$ Rec. PK fertilizer during period of incubation

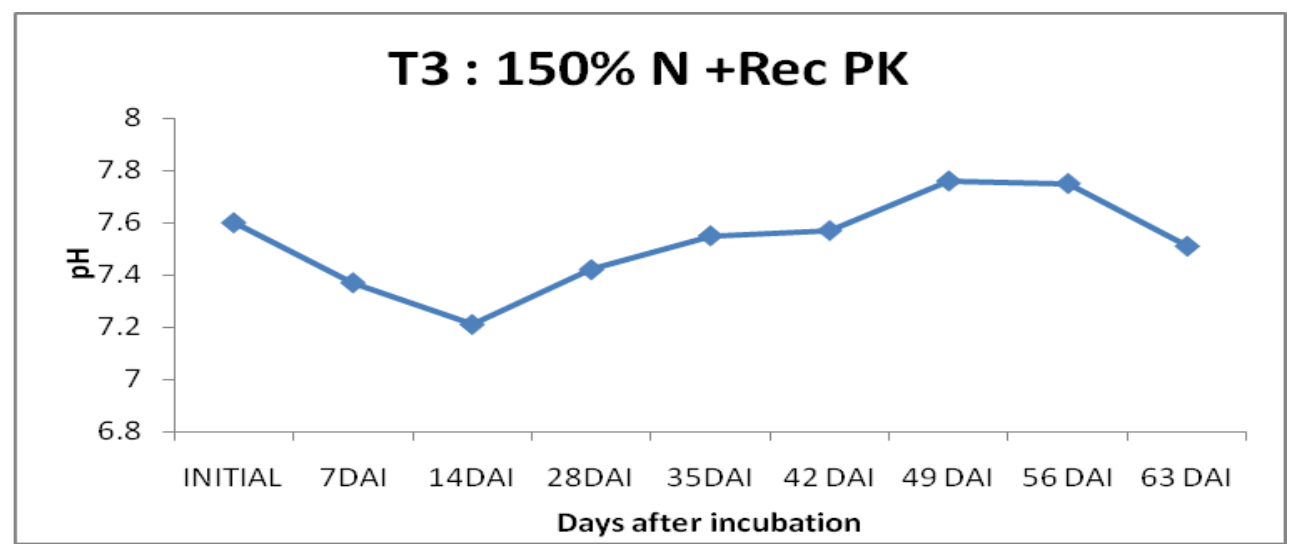


Fig.3a Pattern of change in soil reaction changing pattern by $125 \% \mathrm{P}+$ Rec. NK fertilizer during period of incubation

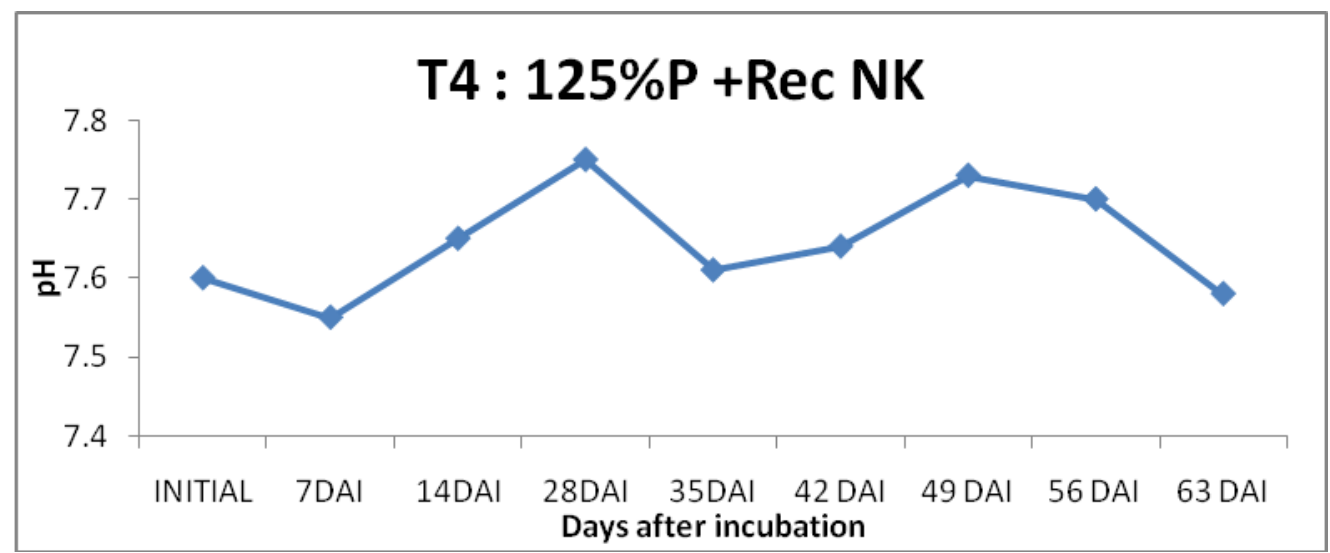

Fig.3b Pattern of change in soil reaction by $150 \% \mathrm{P}+$ Rec. NK fertilizer during period of incubation

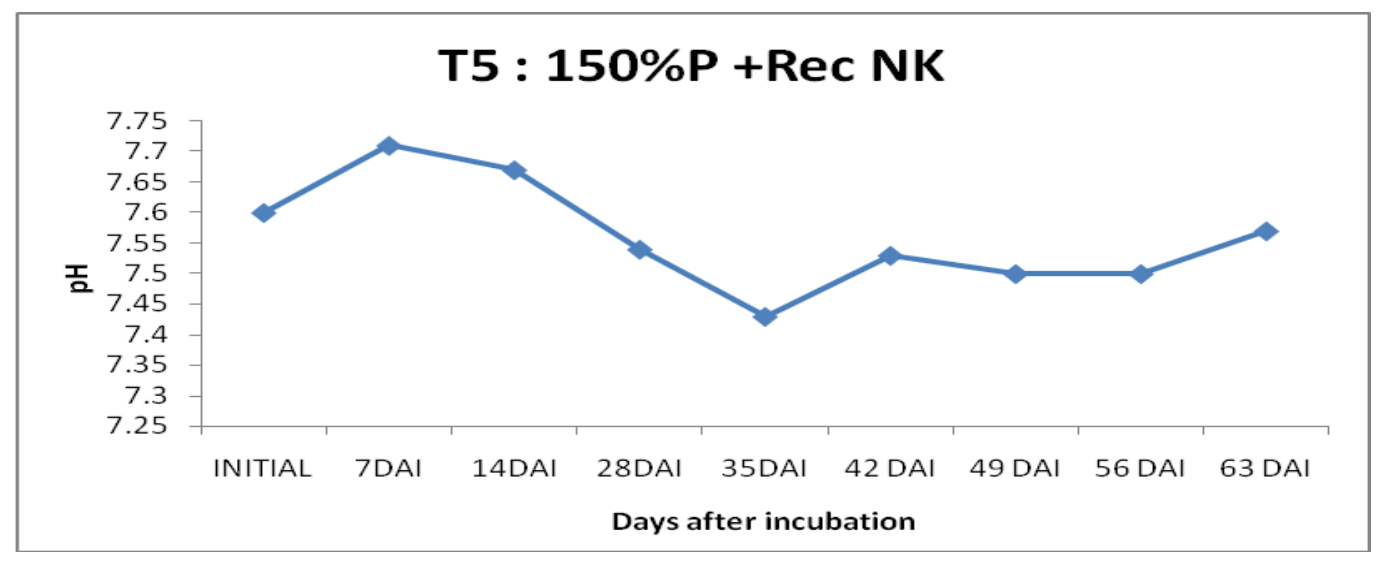

Fig.4a Pattern of change in soil reaction changing pattern by $125 \% \mathrm{~K}+$ Rec. NP fertilizer during period of incubation



2116 
Fig.4b Pattern of change in soil reaction changing pattern by $150 \% \mathrm{~K}+\mathrm{Rec}$. NP fertilizer during period of incubation

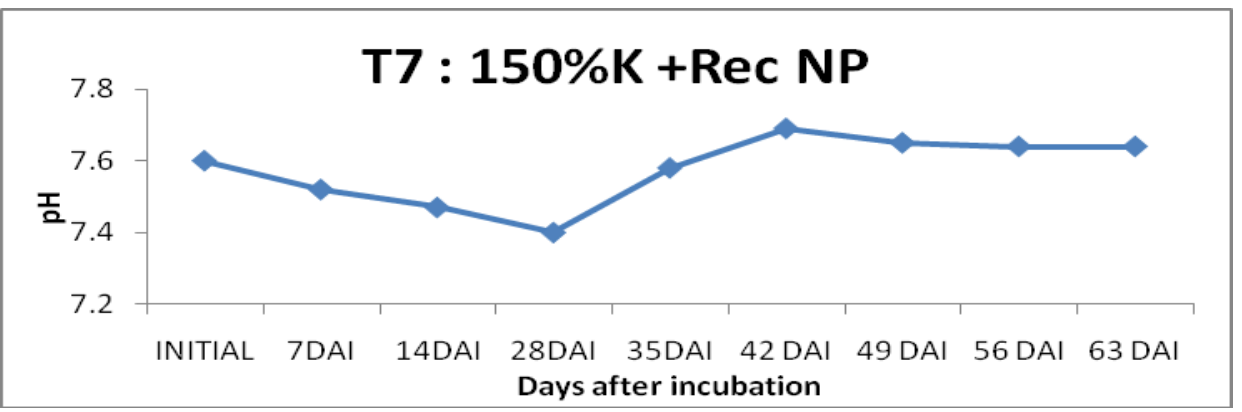

Fig.5a Soil Salinity changing pattern by $125 \% \mathrm{~N}+$ Rec PK during period of incubation

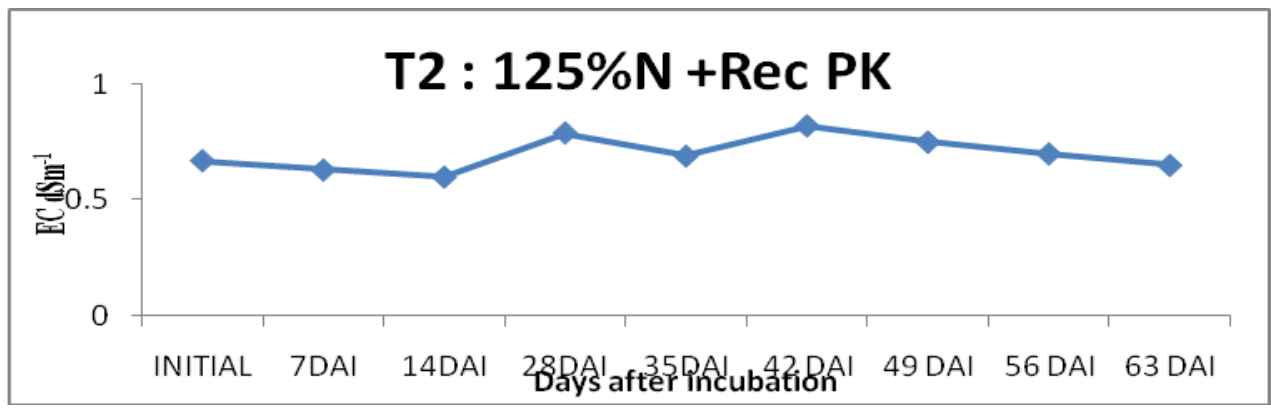

Fig.5b Soil Salinity changing pattern by $150 \%$ N + Rec PK during period of incubation

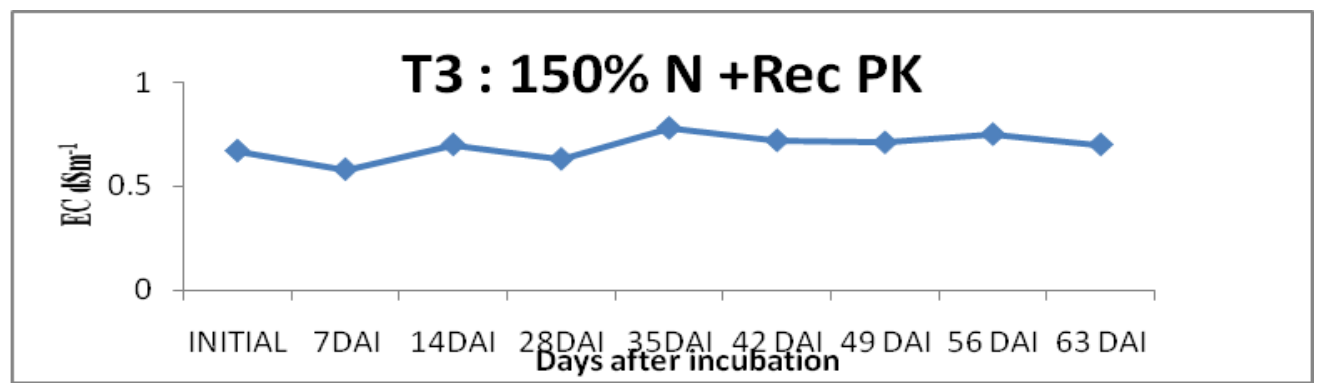

Fig.6a Soil Salinity changing pattern by $125 \% \mathrm{P}+$ Rec NK during period of incubation

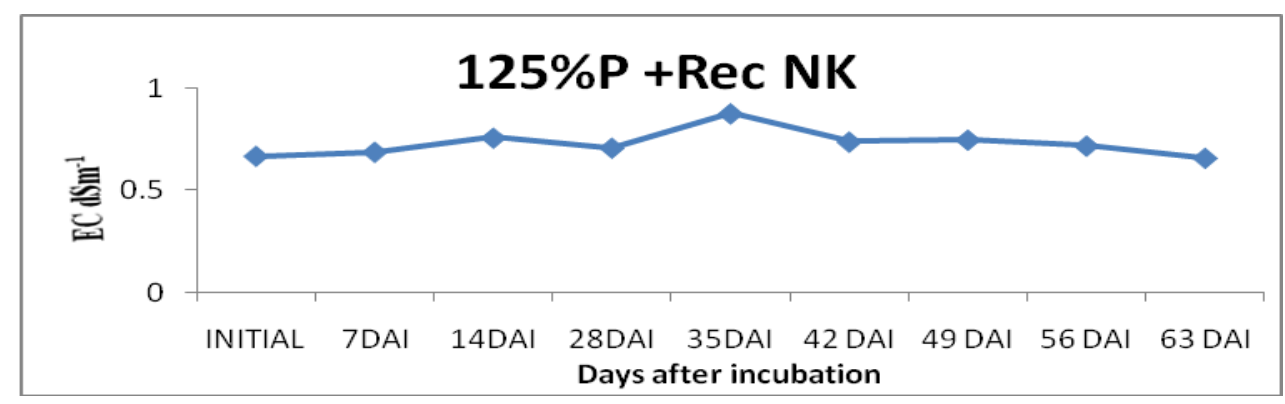


Fig.6b Soil Salinity changing pattern by $150 \% \mathrm{P}+$ Rec NK during period of incubation

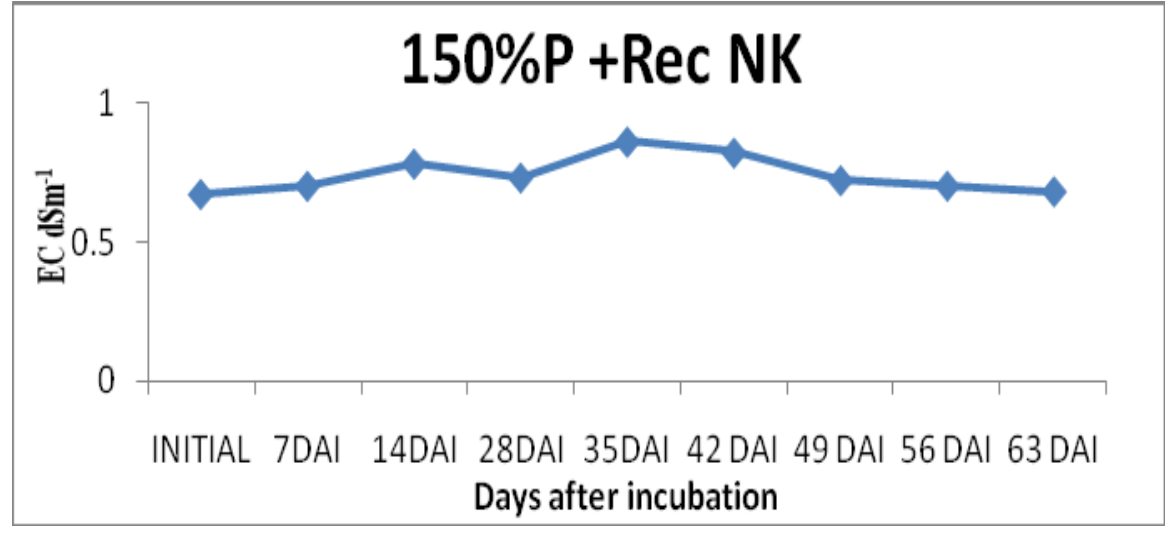

Fig.7a Soil Salinity changing pattern by $125 \% \mathrm{~K}+$ Rec NP during period of incubation

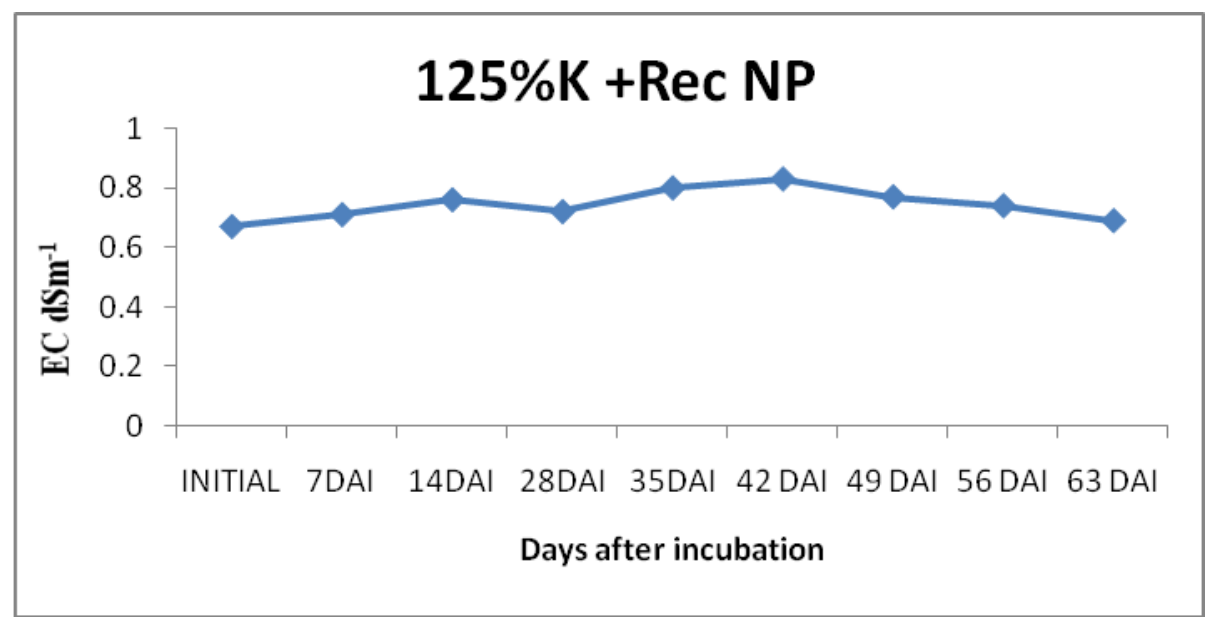

Fig.7b Soil Salinity changing pattern by $150 \% \mathrm{~K}+$ Rec NP during period of incubation

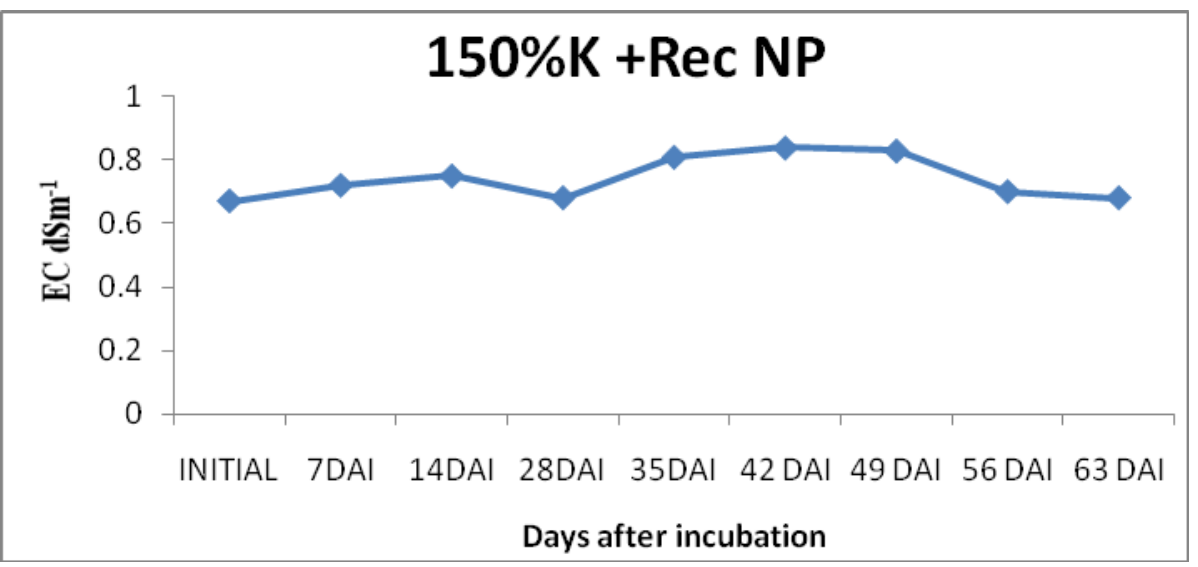


It is also in agreement with the findings of Meyer et al., (2018), who reported that increase in $\mathrm{pH}$ was observed in soil reacted with DAP for $1 \mathrm{hr}$ and lowering of $\mathrm{pH}$ values of the soil was noted after $24 \mathrm{hrs}$. The increase in $\mathrm{pH}$ values may be due to the increasing $\mathrm{HPO}_{2}^{-}$ion in applied phosphate compounds and with the continuation of the process, more soils came into contact with the fertilizer, leading to the rise in $\mathrm{pH}$ of the solution which then became supersaturated with respect to phosphate compounds. The decrease in $\mathrm{pH}$ may also be due to the displacement of hydrogen ions from phosphate in solution as a result of precipitation of phosphate ions.

\section{Potassium fertilizers on soil reaction}

Generally MOP has no effect on soil acidification. In $\mathrm{K}$ treatments, soil got acidified and reached its maximum reduction in the middle of the incubation period. Initial value of $\mathrm{pH}$ was 7.6 and the maximum reduction was 7.4 recorded @ 28 DAI in both the $125 \%$ and $150 \% \mathrm{~K}$ treated soil (Fig. 4a and $4 \mathrm{~b}$ ). In this study, use of $\mathrm{K}$ fertilizers in soil had minimum effect in altering the soil $\mathrm{pH}$. This is also supported by Reis et al., (2018) who observed that potassium fertilizer levels did not affect soil $\mathrm{pH}$. Although decrease in soil $\mathrm{pH}$ with the application of fertilizers was expected, it was not seen in this case of study.

If the soil is acidic, the soluble MOP increases the total ionic strength, displaces $\mathrm{Al}$ into solution, and so decreases $\mathrm{pH}$. Under normal circumstances showing near neutral $\mathrm{pH}$ values, MOP would not alter the $\mathrm{pH}$ much. However an acidic soil may show decreased $\mathrm{pH}$ values as there are ample amounts of $\mathrm{H}^{+}$ ions adsorbed that comes into the soil solution as a result of exchange with $\mathrm{K}$. Hence addition of $\mathrm{K}$ can acidify an acidic soil further and no influence over alkaline soils (Roberto et al., 2016)

\section{Effect of NPK fertilizers on soil salinity}

\section{Urea on soil salinity}

Dissolution of inorganic fertilizers added to soil has several influences on soil physicochemical properties especially soil salinity. In $100 \%$ NPK treated soil, the salinity level got raised and reached a maximum of $0.88 \mathrm{dS} \mathrm{m}^{-1}$ at 35 days after incubation after that it declined in the succeeding weeks. Lopsided pattern of variation in salinity was seen in soil with excess urea. In first two weeks, EC got reduced from 0.67 to $0.60 \mathrm{dS} \mathrm{m}^{-1}$ after that the trend altered and utmost salinity of 0.82 $\mathrm{dS} \mathrm{m}{ }^{-1}$ was reached during $42^{\text {nd }}$ days after incubation in 125 percent $\mathrm{N}$ treated soil (Fig. 5a). In 150 per cent $\mathrm{N}$ applied soil, complete ups and down level in salinity seen throughout the period (Fig 5b). Comparing both $\mathrm{N}$ treatments, maximum unit change in EC was recorded in 125 percent $\mathrm{N}$ treated soil. Such N induced salinity levels may affects the nitrification process adversely in soil, which resulted in $\mathrm{NO}_{2}$ accumulation in the soil (Akhtar and Alam, 2001).

\section{DAP on soil salinity}

Increasing tendency in the electrical conductivity was contributed by $\mathrm{P}$ fertilizer addition. Soil solution get enriched by soluble salts through the addition of DAP. Among the treatments, highest salinization was noticed in the 125 and $150 \% \mathrm{P}$ treated soil. In 125 and $150 \%$ DAP treated soil high degree of salinity was recorded i.e., from 0.67 to $0.88 \mathrm{dS} \mathrm{m}^{-1}$ and 0.67 to $0.86 \mathrm{dS} \mathrm{m} \mathrm{m}^{-1} @ 35$ DAI respectively (Fig. 6a and 6b). Changing pattern in salinity during the period was 
irregular and reached stability at last week of study. Such salinization pattern was also reported by Naima et al., (2015).

Greater soil salinity caused marked inhibition of the very first step of nitrification during 7 days of incubation, which resulted in lower conversion of $\mathrm{NH}_{4}$ to $\mathrm{NO}_{2}-\mathrm{N}$, and consequently a large amount of $\mathrm{N}$ was present in $\mathrm{NH}_{4}$ form at the greatest salinity level (Akhtar et al., 2012). Irshad et al., (2018) also reported that nitrification of $\mathrm{NH}_{4}$ to $\mathrm{NO}_{3}$ was reduced by salinity.

\section{MOP on soil salinity}

Generally $\mathrm{K}$ fertilizers had notable effect over soil reaction and salinity. Application of K @ 125 and $150 \%$ recommended dose showed similar pattern in EC of soil throughout the study. The maximum EC of $0.84 \mathrm{dS} \mathrm{m}^{-1}$ from initial value $\left(0.67 \mathrm{dS} \mathrm{m}^{-1}\right)$ was observed on $42^{\text {nd }}$ day by the application of $150 \%$ recommended $\mathrm{K}$ (Fig. 7a). However the highest salinity level was observed during 42 DAI in both the 125 and 150 percent MOP applied soil (Fig. 7a and 7b).

Potassium fertilizer application, usually based on chloride or sulfate salts, could contribute to soil salinization due to their high salt index (Pirhadi et al., 2018). It is also supported by Santos (2013) who observed the increased soil salinity due to higher application of MOP (300 lb/acre).

The present study revealed that the soil reaction and electrical conductivity were influenced by inorganic fertilizer addition. Excess urea application (150\% recommended $\mathrm{N})$ showed a prominent acidifying impact on soil. While DAP and MOP application did not impact soil $\mathrm{pH}$ considerably as compared to urea. High salinity levels was noticed with
DAP at the rate of $150 \% \mathrm{P}+\mathrm{Rec}$ NK. Among NPK sources included, MOP had less effect on both soil $\mathrm{pH}$ and EC. Hence long term application of excess inorganic fertilizers could undeniably make negative effects to the crop in altering the soil physico chemical properties.

\section{References}

Adhikari, T., Kundu, S., and Rao, A. S. 2014. Microbial solubilization of phosphorus from nano rock phosphate. Journal of Agricultural Science and Technology. A, $4(6 \mathrm{~A}$

Darusman, L.R., Stone, D.A., Janssen, K.A., Long, J.H., 1991. Soil properties after twenty years of fertilizers with different nitrogen sources. Soil Sci. Soc. Am. J. 55: 1097-1100.

Eriksen A B, Kjeldby M and Nilsen S. 1985. The effect of intermittent flooding on the growth and yield of wetland rice and nitrogen-loss mechanism with surface applied and deep placed urea. Plant and Soil 84: 387-401.

Glendining, M.J., D.S. Powlson, P.R. Poulton and Bradbury, N.J. 1996. The effects of long-term applications of inorganic nitrogen fertilizer on soil nitrogen in the Broadbalk Wheat Experiment. The Journal of Agricultural Science. 127(3): 347-363

Hati, K.M., Swarup, A., Mishra, B., Manna, M.C., Wanjari, R.H., Mandal, K.G., Misra, A.K., 2008. Impact of long-term application of fertilizer, manure and lime under intensive cropping on physical properties and organic carbon content of an Alfisol. Geoderma 148: 173-179.

Irshad, M., Hafeez, F., Naseem, M., Rizwan, $\mathrm{M}$ and Al-Wabel, M. I. 2018. Effect of coal and wood ash on phosphorus 
immobilization in different textured soils. Arabian Journal of Geosciences, 11(18): 536.

Keith A. M., Boots B., Hazard C., Niechoj R., Arroyo J., Bending G. D., Bolger T., Breen J., Clipson N., Doohan F. M., Griffin C. T., Schmidt O. 2012. Croxtaxa congruence, indicators and environmental gradients in soil under agricultural and extensive land management. European Journal of Soil Biology, 49: 55-62.

Lu, W. W. 2012. In situ dissimilatory nitrate reduction to ammonium in a paddy soil fertilized with liquid cattle waste. Pedosphere 22: 314-321 (2012).

Magdof, F., Lanyon, L and Liebhardt, B. 1997. Nutrient cycling, transformations and flows: implications for a more sustainable agriculture. Adv. Agron. 60: $1-73$.

McDowell, R., A. Sharpley, P. Brookes and P. Poulton, 2001. Relationship between soil test phosphorus and phosphorus release to solution. Soil Sci., 166: 137149.

Meyer, G., Frossard, E., Mäder, P., Nanzer, S., Randall, D. G., Udert, K. M and Oberson, A. 2018. Water soluble phosphate fertilizers for crops grown in calcareous soils-an outdated paradigm for recycled phosphorus fertilizers? Plant and Soil, 424(1-2): 367-388.

Milosevic N., Govedarica M., Jarak M., Bogdanovic D., Ubavic M and Cuvardic M.1995. Number of microorganisms and dehydrogenase activity in soils under peas, onion and cabbage. Mikrobiologija 32(2): 259-267.

Muhammad Akhtar and S.M. Alam. 2001. Effect of Incubation Period on Phosphate Sorption from Two P Sources. Journal of Biological Sciences 1 (3): 124-125, 2001.
Naima B. D., Leila H.M and Adil Mihoub. 2015. Effect of Incubation Period of Phosphorus Fertilizer on some Properties of Sandy Soil with Low Calcareous Content, Southern Algeria. Asian Journal of Agricultural Research, 9 (3): 123-131

Olsen, S.R., C.V. Cole, F.S. Watanabe and L.A. Dean, 1954. Estimation of available phosphorus in soils by extraction with sodium bicarbonate. USDA Circular No. 939, United States Department of Agriculture, Washington, DC., USA., pp: 1-18.

Pirhadi, M., Enayatizamir, N., Motamedi, H., and Sorkheh, K. (2018). Impact of soil salinity on diversity and community of sugarcane endophytic plant growth promoting bacteria (Saccharum officinarum 1. var. CP48). Applied ecology and environmental research, 16(1): 725-739.

Reis, V. R. R., Deon, D. S., Muniz, L. C., Garcia, U. S., de Lima Cantanhêde, I. S., de Moraes Rego, C. A. R and de Oliveira Marques, E. 2018. Soil Chemical Attributes under Crop Livestock-Forest Integration System and in Different Land Uses in Mata dos Cocais Region. Journal of Agricultural Science, 10(4): 370.

Richards, L.A., 1954. Diagnosis and improvement of saline and alkali soils. USDA Agriculture Handbook No. 60, Washington, DC., USA., pp: 5-16.

Santos, B. M. 2013. Effects of preplant potassium sources and rates for tomato production. HortTechnology, 23(4): $449-452$.

Sharpley, A.N., 1983. Effect of soil properties on the kinetics of phosphorus desorption. Soil Sci. Soc. Am. J., 47: 462-467. 
Singh, M., Reddy, S.R., Singh, V.P., Rupa and T.R. 2007. Phosphorus availability to rice (Oriza sativa $\mathrm{L}$.)-wheat (Triticum estivum L.) in a Vertisol after eight years of inorganic and organic fertilizer additions. Bioresour. Technol. 98: 1474-1481.

Su, Y. Z and Zhao, H. L. (2002). Advances in researches on soil organic carbon storages, affecting factors and its environmental effects. Journal of Desert Research, 22(3): 220-228.
Wardle. D. A. 1992. A comparative assessment of factors which influence microbial biomass carbon and nitrogen levels in soil. Biol. Rev. 67: 321-358.

Wells, N. S., Clough, T. J., Johnson-Beebout, S. E. and Buresh, R. J. Land management between crops affects soil inorganic nitrogen balance in a tropical rice system. Nutr. Cycl. Agroecosyst. 100: 315-332 (2014).

\section{How to cite this article:}

Theresa, K., R. Shanmugasundaram and Kennedy, J.S. 2019. Dynamic Changes in Soil Physico-Chemical Properties with the Application of Inorganic Fertilizers. Int.J.Curr.Microbiol.App.Sci. 8(08): 2111-2122. doi: https://doi.org/10.20546/ijcmas.2019.808.247 